\title{
EKSPLORASI POTENSI ANTI MALARIA SENYAWA BIOAKTIF Moringa oleifera DENGAN PENDEKATAN IN SILICO
}

\author{
Dede Rival Novian \\ Fakultas Kedokteran Hewan, Universitas Nusa Cendana, Nusa Tenggara Timur \\ Email : dede.rival.novian@staf.undana.ac.id
}

\begin{abstract}
Malaria is a global human health problem and also a leading cause of death in tropical and subtropical countries. Over the past fifteen years, the prevalence of malaria has decreased by more than half. However, a new problem emerged, namely the emergence of resistance to existing malaria drugs. Therefore, efforts to develop new malaria drugs are needed to combat the malariad disease. Moringa oleifera is one of the important plants that is widely cultivated in NTT. This plant contains many important pharmacological effects such as anti-asthma, antidiabetic, anti-inflammatory, anticancer, antimicrobial, and others. However, the pharmacological effects of MO plants as antimalarials are not yet clearly known. The aim of this study is to use the in silico approach to investigate the potential of the Moringa oleifera compound which functions as a Plasmodium falciparum dihydrofolate reductase-thymidine synthase (pfDHFR-TS) receptor inhihibitor. The research method used is the in silico approach using TCMSP web based application and molecular docking simulation using USCF Chimera. The results of pharmacological tests and molecular docking simulations show that the bioactive pyhtol compound from Moringa oleifera has potential as a new malaria drug compound. Phytol compound has a MW of 296.6; the number of Hdon and Hacc is 1; $O B$ of $33.82 \%$; TPSA of 20.23 and the number of HL is 2.34. While the energy affinity of pyhtol compounds is $-6.4 \mathrm{kcal} / \mathrm{mol}$.
\end{abstract}

Key words : Molecular docking, Plasmodium falciparum, dihydrofolate reductase-thymidine synthase, Moringa oleifera ,TCMSP, phytol, USCF Chimer, 3UM8.

\section{PENDAHULUAN}

Malaria adalah penyakit berbahaya yang disebarkan oleh nyamuk anopheles betina. Malaria menjadi masalah kesehatan manusia secara global dan juga penyebab utama kematian di negara tropis dan subtropik. Selama lima belas tahun terakhir, prevalensi malaria berkurang hingga lebih dari setengahnya. Namun, muncul masalah yang baru, yakni timbulnya resistensi terhadap obat malaria yang sudah ada. Oleh karena itu, upaya untuk mengembangkan obat malaria baru sangat dibutuhkan untuk memerangi penyakit malaria tersebut. ${ }^{1}$ Malaria disebabkan oleh infeksi parasit protozoa milik genus Plasmodium yang ditularkan oleh spesis nyamuk Anopheles betina. ${ }^{2}$ Banyak obat telah dikembangkan untuk melawan malaria, diantaranya golongan kuinolin (kloroquin, kuinin, mefloquin, amodiakuin, primaquin), antifolat (pirimetamin, proguanil dan sulfadoksin), dan turunan artisinin (artemisinin, artesunat, hidrokarbon). ${ }^{3}$

Saat ini, ada obat yang efektif untuk mengobati dan mengendalikan malaria. Namun, $P$. falciparum memiliki kemampuan untuk mengembangkan resistensi terhadap pengobatan tersebut. Sehingga perlu dikembangkan obat dan target reseptor antimalaria yang baru. ${ }^{1}$ Resistensi terhadap obat antimalaria disebabkan oleh mutasi titik pada enzim Dihydrofolate reductase (DHFR) 
Eksplorasi potensi anti malaria senyawa bioaktif Moringa oleifera dengan pendekatan in silico.

dan Dihydropteroate synthase (DHPS). Dua enzim tersebut adalah enzim kunci dalam jalur biosintetik folat yang menjadi target antifolat. ${ }^{3}$ Resistensi terhadap inhibitor DHFR dan DHPS disebabkan oleh mutasi dari gen yang mengkode enzim tersebut. ${ }^{4}$

$$
\text { Moringa oleifera }(\mathrm{MO}) \text { adalah salah }
$$
satu tanaman penting yang banyak dibudidayakan di Nusa Tenggara Timur (NTT). Tanaman MO termasuk dalam golongan Moringaceae (Gambar 1). Tanaman ini banyak mengandung efek farmakologi yang penting seperti antiasma, antidiabetes, hepatoprotektif, antiinflamasi, kesuburan, antikanker, antimikroba, antioksidan, kardiovaskuler, antiulkus, aktivitas CNS, anti alergi, penyembuhan luka, analgesik, dan aktivitas antipiretik. Setiap bagian dari tanaman MO mengandung banyak nutrisi dan vitamin yang penting untuk tubuh seperti vitamin $A$, vitamin $\mathrm{C}$ dan protein. Selain itu, MO juga mempunyai senyawa bioaktif hasil dari metabolisme sekunder seperti alkaloid, kina, saponin, flavonoid, tanin, steroid, dan glikosida. Terakhir, tanaman MO mengandung minyak dan lemak. ${ }^{5}$ Namun demikian, khasiat tanaman MO terhadap malaria belum diteliti lebih jauh, sehingga perlu dilakukan penelitian antimalaria dari tanaman $\mathrm{MO}$ ini.

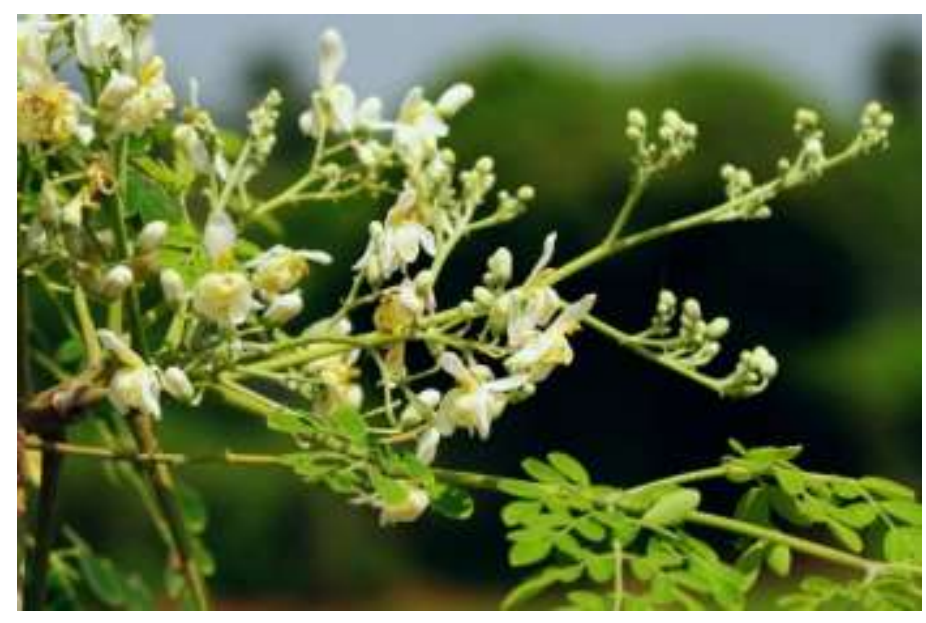

Gambar 1. Tanaman Moringa oleifera

Sejalan dengan hal di atas, pendekatan komputasi telah banyak diterapkan pada aspek biologi molekuler dan penelitian medis. Metode berbasis struktur, seperti docking protein-ligan, adalah metode yang efisien dan andal untuk penemuan dan desain obat baru. Metode simulasi docking dapat menjelaskan interaksi dan mekanisme pengikatan antara target protein dan ligan yang sesuai. ${ }^{6}$ Selain itu, Sistem database juga menyediakan sifat farmakologis terkait penyerapan, distribusi, metabolisme, dan ekskresi (ADME), bioavailabilitas oral dan waktu paruh. $^{7}$

Tujuan dari penelitian ini adalah menggunakan pendekatan docking untuk menyelidiki potensi senyawa bioaktif Moringa oleifera yang dapat berfungsi sebagai inhihibitor reseptor Plasmodium falciparum dihydrofolate reductase-thymidine synthase (pfDHFR-TS). Dalam studi ini, efek farmakologi senyawa bioaktif dari Moringa oleifera di analisis secara in silico menggunakan web based aplication Traditional Chinese Medicine Systems 
Eksplorasi potensi anti malaria senyawa bioaktif Moringa oleifera dengan pendekatan in silico.

Pharmacology Database and Analysis

Platform (TCMSP). Selanjutnya dilakukan simulasi docking antara senyawa bioaktif Moringa oleifera dengan reseptor pfDHFR-TS dari plasmodium malaria.

\section{METODE PENELITIAN}

\section{Alat dan Bahan}

Satu set komputer personal dengan Quad Core Processor (Intel Core 17), RAM 8 gigabyte, Graphic Card NVIDIA Ge Force GTS 940032 core GPU dan sistem operasi LINUX Ubuntu versi 18.04 LTS. Struktur dua dimensi (2D) dan tiga dimensi (3D) senyawa bioaktif Moringa oleifera dan senyawa obat dibuat menggunakan software MarvinSketch V15.8. ${ }^{8}$ Reseptor antimalaria yaitu Plasmodium falciparum dihydrofolate reductase-thymidine synthase (pfDHFR-TS) (PDB ID: $3 \mathrm{UM} 8)^{9}$ diunduh dari database PDB (http://www.rcsb.org/pdb). Sturuktur 3D senyawa bioaktif tanaman MO yang diuji terdiri dari senyawa 1-Hexadecanol, Hexadecanoic acid, 9- Octadecenamide, Oleic acid, dan Phytol $^{10}$, sedangkan senyawa obat malaria yang berfungsi sebagai kontrol positif adalah quinone. Selanjutnya struktur 3D senyawa bioaktif dan obat dilakukan minimisasi energi dengan software avogadro versi $1.2^{11}$ dan diuji efek farmakologinya menggunakan web based application TCMSP (http://lsp.nwu.edu.cn/tcmsp.php). ${ }^{12,13,14,15,16,17}$, 18 Format struktur kimia diubah software OpenBabelG UI versi $2.3 .2^{19}$ dan visualisasi bentuk molekul menggunakan Discovery Studio Client V4.5. Sedangkan metode docking dilakukan menggunakan program UCSF Chimera. ${ }^{20}$

\section{ADME dan Toksisitas (ADMET)}

Hasil skrining senyawa bioaktif dan senyawa obat menggunakan web based application TCMSP dievaluasi dengan lima aturan Lipinski $(\mathrm{RO} 5)^{22}$ dan kriteria obat yang disarankan oleh TCMSP. Menurut lipinksi ${ }^{24}$ kritria obat adalah memiliki massa molekul kurang dari 500 dalton; lipofilisitas tinggi (dinyatakan sebagai logp kurang dari 5), kurang dari 5 donor ikatan hidrogen; kurang dari 10 akseptor ikatan hidrogen dan daya tahan molar antara 40-130. Sedangkan menurut TCMSP ${ }^{12,13,14,15,16,17,18}$ senyawa yang baik digunakan sebagai obat harus memiliki aturan dasar sebagai obat yaitu, ketersediaan hayati oral $(\mathrm{OB})$ : $\geq 30 \%$; $\mathrm{DL} \geq 0,18$; penetrasi senyawa ke otak $(\mathrm{BBB}):<-0,3$ adalah nonpenetrasi, BBB dari $-0,3$ hingga $+0,3$ adalah penetrasi sedang dan $\mathrm{BBB}>0,3$ adalah penetrasi kuat; HL: waktu paruh obat $\leq 4$ jam: adalah kelompok eliminasi cepat, HL antara 48 jam adalah kelompok eliminasi sedang dan kemiripan obat $(\mathrm{HL}) \geq 8$ jam adalah kelompok eliminasi lambat; polaritas molekul (TPSA): kurang dari 60 adalah membran sel yang permeabel; jumlah rotasi (RBN): jumlahnya memenuhi kriteria 10 atau lebih sedikit.

Uji efek farmakologi sangat perlu dilakukan karena efek Farmakokinetik dan toksisitas yang buruk adalah penyebab kegagalan dalam proses pengembangan obat. Nilai ADME dan Toksisitas diprediksi menggunakan web based application TCMSP, sedangkan energi afinitas resetor malaria dengan ligan dapat dihitung menggunakan pendekatan docking, sehingga dapat mempercepat proses penemuan obat.

\section{Analisis Docking}

Proses docking menggunakan program UCSF Chimera dan skrining efek farmakologi diprediksi menggunakan web based application TCMSP. Pendekatan docking menggunakan program UCSF 
Eksplorasi potensi anti malaria senyawa bioaktif Moringa oleifera dengan pendekatan in silico.

Chimera dapat memberikan pose konformasi terbaik di situs pengikatan kompleks proteinligan. Prosedur docking terdiri dari dua langkah berikut: (1) mengidentifikasi dan memilih wilayah protein sebagai situs aktif untuk docking dan (2) proses docking untuk kandidat ligan terbaik ke situs yang dipilih. Situs pengikat yang dikonfirmasi ini digunakan untuk menghitung interaksi antara semua senyawa bioaktif potensial dan senyawa obat dengan reseptor 3UM8. Kemudian UCSF Chimera menghitung energi afinitas antara konformasi protein dan ligan tersebut. Selanjutnya energi afinitas tersebut dibandingkan dengan energi dari senyawa kontrol positif. Semakin kecil nilai afinitas nya maka senyawa bioaktif tersebut semakin stabil dan berpotensi menjadi senyawa obat.

\section{HASIL DAN PEMBAHASAN}

\section{ADME dan Toksisitas}

Web based application TCMSP menghitung nilai $A D M E$ dan toksisitas suatu senyawa berdasarkan sifat molekul, yaitu berat molekul (MW), koefisien partisi antara oktanol dan air, sifat lipofilisitas (AlogP), donor ikatan hidrogen (Hdon), akseptor ikatan hidrogen (Hacc), ketersediaan hayati oral
$(\mathrm{OB})$, penetrasi senyawa ke otak (BBB), kemiripan obat (DL), polaritas molekul (TPSA), jumlah rotasi (RBN), dan waktu paruh obat $(\mathrm{HL})$. Hasil ADME dan toksisitas senyawa bioaktif dan senyawa kontrol positif ditunjukkan oleh Tabel 1.

Berdasarkan hasil pengamatan dari Tabel 1, senyawa bioaktif phytol paling banyak memenuhi aturan senyawa obat dibandingkan senyawa bioaktif yang lain. Senyawa phytol memilki MW kurang dari 500 yaitu 296,6, Hdon kurang dari 5 yaitu 1, Hacc kurang dari 10 yaitu 1 , OB lebih dari $30 \%$ yaitu $33,82 \%$, TPSA kurang dari 60 yaitu 20,23 dan waktu paruh obat kurang dari 4 Jam yaitu 2,34 jam. Namun demikian senyawa pyhtol juga memiliki kelemahan karena memiliki lipofilitas (AlogP) lebih dari 5 yaitu 7,34, penetrasi senyawa ke otak tinggi lebih dari 0,3 yaitu 0,85 , kemiripan obat kurang dari 0,18 yaitu 0,13 dan jumlah rotasi lebih dari 10 yaitu 13. Berdasarka Tabel 1. sifat fisikokimiawi, termasuk di dalamnya ada sifat penyerapan, distribusi, metabolisme, dan ekskresi (ADME), bioavailabilitas oral dan waktu paruh dari senyawa phytol memiliki potensi sebagai sebagai obat herbal.

Tabel 1. Sifat fisikokimiawi senyawa bioaktif Moringa oleifera

\begin{tabular}{ccccccc}
\hline \multirow{2}{*}{$\begin{array}{c}\text { Sifat } \\
\text { Fisikokimia }\end{array}$} & 1-Hexadecanol & $\begin{array}{c}\text { Hexadecanoic } \\
\text { acid }\end{array}$ & $\begin{array}{c}\text { 9-Octadece } \\
\text { namide }\end{array}$ & Oleic acid & Phytol & Quinone\# \\
\cline { 2 - 7 } MW & $242,50^{* *}$ & $256,48^{* *}$ & $281,54^{* *}$ & $282,52^{* *}$ & $296,6^{* *}$ & $108,10^{* *}$ \\
AlogP & 6,45 & 6,37 & 6,23 & 6,84 & 7,34 & $0,41^{* *}$ \\
Hdon & $1^{* *}$ & $1^{* *}$ & $2^{* *}$ & $1^{* *}$ & $1^{* *}$ & $0^{* *}$ \\
Hacc & $1^{* *}$ & $2^{* *}$ & $2^{* *}$ & $2^{* *}$ & $1^{* *}$ & $2^{* *}$ \\
OB (\%) & 13,32 & 19,30 & $31,20^{*}$ & $33,13^{*}$ & $33,82^{*}$ & $33,58^{*}$ \\
BBB & 1,07 & 1,00 & 1,07 & 0,78 & 0,85 & 0,05 \\
DL & 0,08 & 0,10 & 0,14 & 0,14 & 0,13 & 0,02 \\
TPSA & $20,23^{*}$ & $37,30^{*}$ & $43,09^{*}$ & $37,30^{*}$ & $20,23^{*}$ & $34,14^{*}$ \\
RBN & 14 & 14 & 15 & 15 & 13 & $0^{*}$ \\
HL (jam) & $0^{*}$ & $0^{*}$ & 4,84 & 4,99 & $2,34^{*}$ & 12,07 \\
\hline
\end{tabular}

Keterangan:

\# : Senyawa kontrol positif

* : Memenuhi aturan TCMPS sebagai kandidat obat

** : Memenuhi aturan Lipinski sebagai kandidat obat 
Eksplorasi potensi anti malaria senyawa bioaktif Moringa oleifera dengan pendekatan in silico.

\section{Analisis Docking}

Simulasi docking menggunakan program UCSF Chimera. Proses simulasi docking terjadi dalam dua tahap: tahap pertama penentuan sisi aktif (Gambar 2) sebagai situs terjadinya reaksi antara reseptor 3UM8 dengan ligan, tahap kedua menghitung energi afinitas dari hasil interaksi reseptor dan ligan pada situs aktif (tabel 2). Visualisasi reseptor 3UM8 ditunjukkan oleh Gambar 2.
Gambar 2 menunjukkan tidak ada perbedaan konformasi dari reseptor 3UM8 sebelum dilakukan docking dengan setelah penentuan gridbox sisi aktif reseptor. Gridbox ditunjukkan oleh kubus yang berwatna hijau. Gridbox yang digunakan sebagai situs aktif dalam simulas dokcing adalah koordinat $x$ yaitu 29,72, koordinat y yaitu 5,25 dan korrdinat $z$ yaitu $58.31 .^{21}$
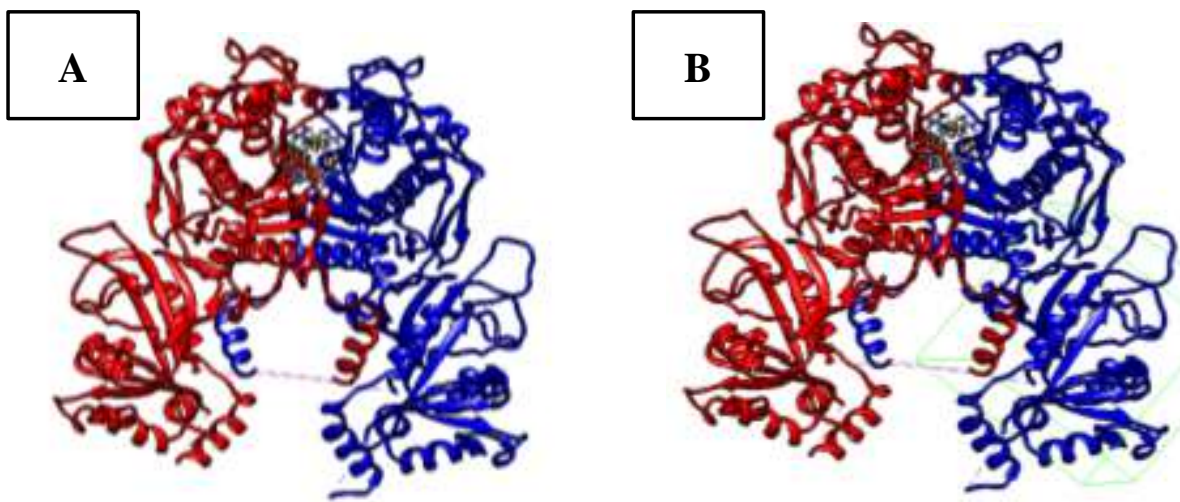

Gambar 2. Reseptor 3UM8. (A) Sebelum dilakukan docking. (B) Penentuan gridbox sisi aktif reseptor ligan

Berdasarkan hasil analisis dari tabel 2, senyawa Hexadecanoic, 9-octadecenamide acid dan phytol memilki energi afinitas yang paling lebih rendah dari senyawa kontrol positif. Dengan demikian ketiga senyawa tersebut memiliki interaksi reseptor dan ligan yang paling stabil sehingga bisa digunakan sebagai kandidat obat.

Tabel 2. Energi afinitas ligan protein
Berdasarkan analisis dari Tabel 1 dan 2, maka senyawa pyhtol adalah yang paling berpotensi dijadikan sebagai obat herbal. Hal ini disebabkan karena senyawa pyhtol memLiki energi afinitis yang lebih rendah dari senyawa kontrol positif $(-5,7 \mathrm{kcal} / \mathrm{mol})$ yaitu $6,4 \mathrm{Kcal} / \mathrm{mol}$ (Tabel 1). Selain itu, senyawa pyhtol juga memLki sifat ADME dan Toksisitas yang mirip dengan obat (Tabel 2).

\begin{tabular}{cc}
\hline Nama Senyawa bioaktif & Energi \\
\hline 1-Hexadecanol-ethol & $-5,3$ \\
Hexadecanoic acid & $-6,0$ \\
9-octadecenamide & $-5,9$ \\
Oleic acid & $-6,1$ \\
Phytol & $-6,4$ \\
Quinone $^{\#}$ & $-5,7$ \\
\hline
\end{tabular}

Keterangan

\#: senyawa kontrol positif 

silico.

\section{KESIMPULAN}

Berdasarkan hasil uji farmakologi dan simulasi molecular docking, senyawa bioaktif phytol dari Moringa oleifera memiliki potensi sebagai senyawa obat malaria baru. Senyawa phytol memilki MW yaitu 296,6; Hdon dan Hacc yaitu 1; OB yaitu 33,82\%; TPSA yaitu 20,23 dan $\mathrm{HL}$ yaitu 2,34. dan energi afinitas sebesar -6,4 kcal/mol. Penelitian ini memerluka tahap uji lanjut in vitro maupun in vivo sebagai langkah validasi antimalaria dari senyawa bioaktif phytol.

\section{DAFTAR PUSTAKA}

1. Cowman AF, Healer J, Marapana D, Marsh K. Malaria: Biology and Disease. Cell 2016; 167:610

2. Cox FE. History of the Discovery Of The Malaria Parasites and Their Vectors. Parasit Vectors 2010; 3:5.

3. Muheet AS et al. African Journal of Pharmacy and Pharmacology 2013;7:148.

4. Cortese JF, Plowe CV. Antifolate Resistance Due To New and Known Plasmodium falciparum Dihydrofolate Reductase Mutations Expressed in Yeast. Mol Biochem Parasitol 1998;1;94(2):20514.

5. Paikra BK, Dhongade HKJ, Gidwani B. Phytochemistry and Pharmacology of Moringa oleifera Lam. Journal of Pharmacopuncture 2017;20[3]:194-200.

6. Novian DR, Ikhwani AZN, Winarso A. Uji Farmakodinamik, Drug-Likeness, Farmakokinetik dan Interaksi Senyawa Aktif Kayu Ular (Strychnos lucida) Sebagai Inhibitor Plasmodium falciparum Secara In Silico. Jurnal Veteriner Nusantara 2019;2(1):70-78.

7. Ru J, Li P, Wang J, Zhou W, Li B, Huang $C$ et al.TCMSP: a database of systems pharmacology for drug discovery from herbal medicines. J.Cheminform 2016;6;1-6.

8. Volford A. Marvin Sketch. Chem Axon Marvin Sketch. 2015
9. Vanichtanankul J, Chitnumsub $P$, Kamchonwongpaisan S, Yuthavong $\mathrm{Y}$. Wild-type Plasmodium falciparum DHFRTS Complexed With Cycloguanil and NADPH. Antimicrob. Agents Chemother 2012; 56: 3928-35

10. Aja PM, Nwachukwu N, Ibiam UA, Igwenyi O, Offor CE, Orji UO. Chemical Constituents of Moringa oleifera Leaves and Seeds from Abakaliki, Nigeria. American Journal of Phytomedicine and Clinical Therapeutics 2014;310-321

11. Hanwell M, Curtis D, Lonie D, et al. Avogadro: An Advanced Semantic Chemical Editor, Visualization, and Analysis Platform. Journal of Cheminformatics 2012;4:8

12. Ertl P. et al. Fast Calculation Of Molecular Polar Surface Area As A Sumof FragmentBased Contributions and Its Application To The Prediction Of Drug Transport Properties. J. Med. Che 2000; 43: 37143717.

13. Madden J. C. In silico Approaches For Predicting ADME Properties. In, Recent advances in QSAR studies.Springer 2010; 283-304.

14. Shen M. et al. Drug-Likeness analysis Of Traditional Chinese Medicines: property Distributions Of Drug-Like Compounds, Non-Drug-Like Compounds and Natural Compounds From Traditional Chinese medicines. J. Cheminformatics 2012; 4: 113.

15. Tao W, et al. Network PharmacologyBased Prediction Of The Active Ingredients And Potential Targets of Chinese herbal Radix Curcumae Formula For Application To Cardiovascular Disease. J. Ethnopharmacol 2013;145: 110.

16. Veber DF et al. Molecular Properties That Influence The Oral Bioavailability of Drug Candidates. J. Med. Chem 2002;45: 2615-2623.

17. Xu X, et al. A Novel Chemometric Method for the Prediction of Human Oral Bioavailability. Int. J. Mol. Sci 2012; 13; 6964-6982. 
Eksplorasi potensi anti malaria senyawa bioaktif Moringa oleifera dengan pendekatan in silico.

18. Yao $\mathrm{Y}$, et al. A novel Systems Pharmacology Model For Herbal Medicine Injection: A Case Using Reduning Injection. BMC Complement. Altern. Med. 2014.

19. O'Boyle, Noel M, Banck, Michael, James, Craig A, et.al. Open Babel: An Open Chemical Toolbox. Journal of Cheminformatics 2011; 3:10.
20. Pettersen, Eric F, Goddard, Thomas D, et.al. Chimera - A visualization System For Exploratory Research and Analysis. Journal of Computational Chemistry 2004; 25(13):1605-1612.

21. David TI, Adelakun NS, Omotuyi OI, et al. Molecular Docking Analysis Of PhytoConstituents From Cannabis Sativa With DHFR. Bioinformation 2018; 14(9): 574579. 